\title{
EXPLORING THE NEXUS BETWEEN SUPPLY CHAIN INTEGRATION, EXPORT MARKETING STRATEGIES PRACTICES AND EXPORT PERFORMANCE: A CASE OF INDONESIAN FIRMS

\author{
Jutamat Sutduean $^{1}$, Ahmad Harakan ${ }^{2}$, Kittisak Jermsittiparsert ${ }^{3}$
}

${ }^{1}$ College of Innovative Business and Accountancy, Dhurakij Pundit University, Bangkok, Thailand, ${ }^{2}$ Faculty of

Social and Political Science, Muhammadiyah University of Makassar, South Sulawesi, Indonesia, ${ }^{3}$ Department for Management of Science and Technology Development, Ton Duc Thang University, Ho Chi Minh City, Vietnam; Faculty of Social Sciences and Humanities, Ton Duc Thang University, Ho Chi Minh City, Vietnam.

Email: ${ }^{1} 607191030012 @$ dpu.ac.th, ${ }^{2}$ ahmad.harakan@unismuh.ac.id, ${ }^{3}$ kittisak.jermsittiparsert@ tdtu.edu.vn

Article History: Received on $25^{\text {th }}$ February 2019, Revised on $28^{\text {th }}$ April 2019, Published on $25^{\text {th }}$ August 2019

\begin{abstract}
Purpose: Given the internationalization of business today, it illustrates the importance of companies looking for overseas market opportunities for the capture of and sustainability of competitive advantage. Following the success of companies from newly developed nations such as the Far East Asian nations of the Republic of Korea and the Republic of China, Taiwan and South East Asian countries such as Singapore, emerging economies are shifting to external sector growth through export industries from the internal sector growth of import substitution industries. Thus, the current study is interested in exploring the nexus between supply chain integration, export marketing strategies and export performance of Indonesian manufacturing firms.
\end{abstract}

Methodology: Employing the survey-based methodology, the SEM-PLS technique is used to test the hypothesized relationships. So, the current study has used SEM-PLS as a statistical tool to answer the research questions raised in this study and research objectives envisaged in the current study.

Results: The findings of the study have provided support to the theoretical foundation and proposed hypothesis of the current study. Current study will be helpful for policymakers and practitioners in understanding the issues related to supply chain risk, supply chain integration and supply chain agility. In the author's knowledge this is among very few pioneering studies on this issue.

Keywords: Supply chain, Marketing strategy, Export performance, Indonesia.

\section{INTRODUCTION}

The increasing international trade has led to the importance of exporting for national economies in this era of globalization. As such, research interest witnessed an increase in the field of export performance and difficulties faced by exporters (Hiremath and Kumari, 2014; Chen et al., 2016; Moussa, 2018). (Aksoy, 2017) stress that exporting has become instrumental in ensuring survival of firms and that they attain competitive advantage in overseas markets to sustain present and future business performance through exporting. Therefore, firms are focusing their effort and resources to export their products. The advent of globalization of markets has led to companies seeking opportunities beyond traditional local markets not only for growth but, increasingly important, for survival. Due to lower resources requirements, the attractive mode of international market entry is exporting. The resources commitment is not as high as compared to green field investments or international joint ventures (Stoian et al., 2011). In the economic development of a country, exports are also essential in Government's economic planning to develop national industries, enhance productivity as well as creating employment. As a consequence, the role of exporting to companies is becoming increasingly important. Given the importance of export markets, the area of export performance has been given more emphasis and attention by both academicians and managers (Sousa, 2004). As a result, the significance of exporting has led to more research focused on the issue of export performance in the immediate past years (Ruzo et al., 2011).

The international expansion of international companies from an emerging economy is mainly achieved by domestic production and exports to overseas markets (Sousa and Lengler, 2009). More studies on export ventures of companies in emerging economies are needed as many companies are still very new to international marketing. In addition, their main way to enter overseas markets is still through conventional exporting. Of particular importance in research is the issue of global marketing strategies that these companies adopt in competing in the international marketplace (Helleiner and Kirshner, 2014; Mungwari, 2018; Myeni and Mvuyana, 2018). Moreover, given the difference in culture among the developing countries compared to advanced economies, the research contributes towards the understanding and development of knowledge on international marketing strategy.

The Asian export is projected to expand by 7.6 percent and 7.8 percent in 2013 and 2014 respectively. Strong ties between the developing economies and industrial countries have been instrumental in enhancing final goods exports from developing countries to developed countries. The globalisation era since 1990 has enhanced Asia's share in the world economy to grow rapidly. Emerging market and developing economies exports are expected to expand by 6.2 percent in 2015 (Helleiner and Kirshner, 2014). The increasing importance of developing economies role, particularly in the Asian 
region, in terms of exporting activity necessitates further research to understand how international marketing strategies contribute to the enhancement of export performance.

\section{LITERATURE REVIEW}

\section{Export Performance}

The field of export performance management is becoming increasingly important to both academicians and practitioners. (Azar and Ciabuschi, 2017) further asserts that rapid globalisation pushes firms to seek markets abroad for the purpose of long-term survival. (Helleiner and Kirshner, 2014) posit that increasing globalisation has made exporting an essential business activity for many companies. Furthermore, in comparison to other international market entry modes, exporting needs minimal human, financial and other resource requirements. Growing internationalization of markets and the resulting challenges contributed to the further interest of the subject of export performance. Exports have not only impact on improved firms' performance but also on countries' economic growth in terms of fast becoming a major part of gross domestic product (GDP) or national income of nations, particularly developing economies. Exporting is fundamental to the business sustainability and scalability of a firm's business performance in a fast globalizing business environment. Competitive edge in global space can have a favorable effect on current and future export performance (Basheer et al., 2019). As a result, more resources and budget are allocated in export ventures. Furthermore, exporting contributes significantly to a country's economic development (Navarro and Boveris, 2009). Export has tremendous impact on nations in terms of increasing economic growth and activities, enhancing national production and industrial development, increasing employment rate and capacity utilisation, building foreign reserves and improving trade balances. Therefore, the main aim of firms and governments is to increase exports.

Export can be conceptually defined as firm's decisions and activities of international marketing. The difference between exporting and other mode of international market entry mode is that the firm does not have control or involved actively in overseas operations (Filipe Lages and Montgomery, 2005). Export can be done in a direct manner where the product is shipped to a direct overseas end buyer or in an indirect manner where it done through a middleman like an agent or distributor. Firms adopt different level of export involvement at different stages of their internationalisation process, from a limited approach in the initial stages to a being a more involved international player in the global market at the later stages. In order to study the export performance of firms at all stages of export involvement, a broad definition of export is adopted. From the strategic management perspective, five major aspects are included in the conceptualisation of export performance [(Magnusson et al., 2013). First, export performance is recognised as the main essence of performance in international strategy. Second, the conceptual and operational aspects of export performance are to include the aspects of business and marketing performance. Third, performance has different meaning to different stakeholders. As most studies consider the impact of international strategies, the definition of export performance ought to take into account external stakeholders that have a direct effect on export performance. Fourth, theoretical definition of export performance is subject to specific context of a study. Lastly, the conceptualisation of export performance should address a certain problem or issue. In essence, export performance is conceptualised as the integrated result of a firm's international marketing (Sousa $e t$ al., 2008) three sub-aspects of export performance that include export sales, export profitability and export growth. These sub-aspects can be measured objectively and subjectively. Objective measurement may include numerical financial returns while subjective measurement may include level of business owner's or manager's satisfaction with the said three subdimensions.

\section{Export Marketing Strategy}

Marketing strategy refers to the manner in which firms respond to external environmental and competitive forces following the enabling of internal forces to achieve marketing goals and objectives through the marketing mix elements that include products, prices, distribution and promotion. (Hafeez et al., 2018) define export marketing strategy as a company's response to the combination of both internal and external environmental factors to attain the export objective through a marketing plan that includes product, pricing, distribution and promotion. The aim of marketing programme is to pursue a company's marketing objectives in a specific market segment (He et al., 2013). Thus, export marketing programme can be referred to as a road map of how a firm react to both internal and external environmental changes through the adoption of marketing mix aspects to meet the firm's export marketing objectives. One of the major factors that influence export performance is export marketing strategy. Past studies indicated a strong correlation between export marketing strategy and export outcome as well as favourable effect of export marketing strategy on export outcome (Gkypali et al., 2015). (Hafeez et al., 2018) discover that majority of exporters that achieved higher export profitability are marketing-based strategists. In essence, most past surveys showed a significant positive influence of export marketing strategy on export performance, and the main export marketing strategy elements are product, price, distribution and promotion. Following the past studies on export marketing strategy of exporters, it is imperative that further understanding is sought of how Malaysian manufacturers manage, align and differentiate their marketing strategy in terms of the four elements of the marketing mix (product, price, distribution and promotion) compared to their marketing strategy in the domestic market. The dynamism of export marketing strategy is fundamental in determining export performance. In diversifying Malaysia's export sector from commodity-based to more value-added products, formulation of effective marketing strategy is important to compete in the increasingly competitive global market. 
Export Marketing Strategy and Export Performance In a seminal work on export performance, investigate the relationship between marketing strategy and export performance. Information is gathered via personal interviews with management personnel involved in export marketing. A pilot study with export marketing managers is conducted to validate the content of the questionnaire, where variables and scales considered irrelevant are taken out in the final instrument. The sampling frame consisted of export companies compiled from both the government export development agencies and from various business associations related to trade (Durmuşoğlu et al., 2012). The unit of analysis, unlike previous studies, is individual product-market export ventures instead of firms. Upon the completion of data gathering, data on 202 export ventures from 79 firms from 16 industries are obtained. In essence, the determinants of product adaptation, promotion adaptation, foreign distributor support, and price competitiveness are examined in terms of their effects on export performance. Export performance, the outcome variable, is operationalised by an importance interval or subjective scale and an objective ratio scale, while all the independent variables are measured by 5-point interval scales. The estimates of path coefficients showed that product modification and foreign channel members' support are significant in favourably influencing export sales. Price competitiveness is found to be not significant while the hypothesis on foreign distributor support is rejected (Morgan et al., 2012).

(Fernández-Mesa and Alegre, 2015) conduct a study to examine factors that determine the export performance of New Zealand manufacturing exporters. The unit of analysis consisted of firms listed in the New Zealand Manufacturer's Federation. A total of 323 firms responded 25 through a mail survey self-administered questionnaire, representing a response rate of 50.3 percent. A final sample of 263 firms is taken into account. Others are firms selling only to domestic market. Based on Aaby and Slater's framework, it is hypothesised that orientation towards marketing, overseas market knowledge, product rarity, quality and service, proportion of sales quotation in local dollars, cultural similarity, and distribution channel support influence export achievement. Export performance, the focus of the study, is measured by both judgmental assessments of export extent of involvement and objective measure of numerical percentage of export sales growth. The independent variables are measured by interval scales. The findings from the variables multiple regressions on export performance are as follows: 1) five factors - marketing orientation, overseas market knowledge, product quality, sales service, cultural similarity, and channel support are discovered to have strong positive association with export sales; 2) the percentage of sales in local dollars is discovered to have a strong negative correlation; 3) the hypothesis of the effect product being unique on export sales is not supported.

(Tan and Sousa, 2015) investigate the determinants and results of export marketing in Thailand, a developing economy's context. This empirical study is based on framework linking export marketing strategy and performance. A preliminary study is carried out among 20 Thai exporting firms with personal interviews with marketing managers. After some modifications, the self-administered questionnaires are posted to a sample consisted of 1,000 Thai small and medium enterprises (SMEs) involved in overseas marketing. The response rate is 15.1 percent or 151 returned questionnaires. Factors such as competition intensity, management commitment, export market features, product features, and cultural similarity are measured by interval scales adapted from 5-point rating scale (Navarro et al., 2010). All export marketing elements are measured via 7-point semantic differential scales while export performance is measured based on respondents' success perception of export involvement on a 10-point bipolar scale (1=unsuccessful; 10=unsuccessful). The individual product-market export involvement is adopted as the analysis unit. The findings support the hypothesis that the competition intensity, management commitment, export market characteristics, and product features significantly influence marketing strategy and overseas market performance. However, cultural affinity and marketing strategy are weakly associated with marketing performance.

(Descotes and Walliser, 2018) examine the linkage between export marketing strategy and performance in an exportoriented d emerging economy of South Korea. Information is collected via a self-administered questionnaire mailed to top management of 180 Korean electronics firms. A total of 58 usable questionnaires are received that represented 32.2 percent of usable questionnaires. It is hypothesised that export marketing performance is influenced significantly in a positive manner by product and pricing modification, direct distribution channels and extent of overseas advertising and trade promotion. Export performance, the dependent variable, is measured by subjectively by 5 -point semantic differential scales. Product adaptation and export pricing is measured by 5-point semantic differential scale. Overseas distribution strategy is measured by percentage of direct exports over manufacturers' total exports while export promotional strategies are measured both by a percentage of international advertising expenses over total exports and trade promotion is assessed by a 5-point rating scale. Effects of overseas marketing programmes on export performance are tested by multiple regression analysis. All the export marketing factors are discovered to be significantly and positively determined the export sales level except overseas advertising expenditure.

(Martin et al., 2017) study the determinants of international marketing performance in the Australian overseas market ventures. The study examined a group of possible factors influencing overseas marketing performance. Specifically, five independent variables are investigated, and they are firm characteristics, product features, market peculiarities, marketing orientation, and international marketing programme. Export marketing outcome is operationalised by a composite continuous measurement scale that includes economic, strategic and overall satisfaction. The antecedents are all measured using interval scales. The single product-market export venture is adopted as the analysis unit. Information is collected through a mail survey of exporting firms located in Queensland, Australia, provided by the Queensland state government 
department. A pilot test among marketing managers of 10 firms is conducted to fine-tune the questionnaire with the final instrument mailed to 1,132 firms involved in exporting. 293 usable questionnaires are returned. The final sample consists of firms from various economic sectors such as agriculture, mining, light industries, metal works, electronics, chemical and the service sectors. The findings support the hypotheses that firm characteristics, market features, and international marketing programmes have strong positive influences on overseas marketing performance (Lee and Griffith, 2004). Product characteristics and marketing orientation, however, are found to be not significant in determining export marketing performance.

The numerous studies conducted and published in the last four decades on the area of export performance reflect the relevance of the issue. Marketing strategy refers to the manner in which companies react to competitive market place. The linkage of marketing strategy in terms of product, pricing, placing and promotion (marketing mix), with export performance has been one of the most studied areas in international marketing 28 research like those by (Julian and O'Cass, 2004). (Lee and Griffith, 2004) create a comprehensive framework that illustrates the association between marketing strategy and business performance. They further conceptualise exporting as a strategic reaction to the competitive business environment based on a company's resources and capabilities. Based on this theoretical perspective, they assert the suitability of adopting the underpinning theory of a strategy-environmental co-alignment. In this framework, exporters are seen to adapt their strategies in accordance with the internal and external environmental changes to attain superior business performance.

Prior studies have shown that firms choose overseas markets based on market potential and related market risks Upon the selection of overseas target markets, market entry success is subject to the planning and execution of international marketing programmes that are in line with the companies' strengths and external opportunities and how the companies overcome their internal weaknesses and mitigate external risks. In other words, the capability to fulfil international customers' needs significantly influences overseas market performance (Descotes and Walliser, 2018). As such, overseas market features should give rise to external opportunities and threats for exporters that in turn affect their export marketing strategies. Hence, the key decision by firms in their overseas marketing strategies is the level of standardisation or modification to local environment (Ruskowski and Pauwels, 2016). The degree of modification versus standardisation is contingent of firm and market environmental factors. Hence, overseas marketing strategy can be viewed as the extent of modification or standardisation (Cui et al., 2014) of the marketing elements in a particular overseas market, which directly affect overseas marketing performance. (Cui et al., 2014) conduct a research, among others, to study the impact of overseas marketing programmes on international marketing performance of Brazilian firms. The study looks at the effect of the marketing mix factors on export outcome of companies. Specifically, it analyses the effects of product, price, promotion and distribution modification on the export performance of firms. The study adopts the analysis unit of export venture of a specific product to a particular market. A multi industry sample of 1,000 Brazilian companies is used where questionnaires with a mail prepaid response envelope are sent to management personnel involved in exporting of firms' products, followed by reminder letters. Upon the completion of the data collection, 201 usable questionnaires are returned.

The results show that product adaptation has a favorable impact on export achievement, which is in line with the results obtained by (Julian, 2018) supports the recommendation to modify products when entering the international markets. Hence, the ability of firm to respond to local conditions of overseas markets through product adaptation strategy reflects the firm's international competence (Douglas \& Craig, 1989). Findings also indicate that adaptation of promotion has a positive relationship with export performance. The findings are consistent with the results of studies by (Lengler et al., 2013). However, the hypothesis of a positive correlation between price modification and export achievement of the firm is rejected. Instead, the results indicate a negative price modification influence on export achievement of the company. The findings are similar to those discovered. The findings suggest that companies should strategies to standardize prices to improve their export achievement level in the international market. A possible rationale to this situation is that price is associated with a consistent product's image and quality across various markets. Therefore, price modification strategy could have a negative effect on the brand image across nations, and as a result have a negative impact on export performance, particularly in today's situation where consumers are highly internationally mobile. (Morgan et al., 2012) also discover a strong negative correlation between distribution modification and export achievement in line with findings. Possible reasoning is that it is better for a company to use the same distribution strategy in other markets as the same distribution strategy is cheaper and easier to implement. Furthermore, without a company's close relations with overseas distribution channel members, distribution adaptation may lead to increased level of conflicts in the firm's distribution strategy, which may result in a poor performance. (Lengler et al., 2013) in a research on export performance of small and medium firms in Malaysia, suggest that there is a need for more research on the impact of competitive strategy, that can include export marketing strategy, on export performance. In the said study, competitive strategy refers to the firm's the alignment of internal aspects in response to the external market environment. Given the importance of export marketing strategy in ascertaining export performance, there is a need to study the specific strategic aspects in terms of aligning internal elements.

\section{Supply Chain integration}

It is important to consider the supply chain integration dimensions particularly for interpreting the means by which individuals' function and how they jointly operate. Appendix A indicates a summarized body of literature to analyze 
several aspects of supply chain integration. A few authors have observed the supply chain integration as a one way or a single construct (Gkypali et al., 2015). whereas other authors have classified the SCI as the external and internal integration of operations; (Durmuşoğlu et al., 2012), also a few others have integrated the deeper perspectives such as multi-dimensional SCI (Morgan et al., 2012). However, each dimension indicates significant dimensions related to supply chain integration, having considerable convergence among them, thus making it hard to solve these relations.

The diverse SCI dimensions can be divided into three groups, namely internal integration, supplier integration, and customer integration. Supplier and customer integration are also known as external integration, defined as the extent of association between the manufacturers and the external partners for shaping the inter-organizational practices, processes, and strategies into synchronized and collaborative processes. Customer integration includes fundamental capabilities that arise as a result of partnership with the critical customers on the other hand, supplier integration accounts for the fundamental competencies that arise as a result of partnership with the critical suppliers (Fernández-Mesa and Alegre, 2015). Contrarily, internal integration covers activities of the manufacturers, thus, indicating the extent to which a manufacturer shapes the strategies, processes, and practices of its organization in a synchronized system for the purpose of satisfying the requirements of its customers as well as for establishing an efficient connection with the suppliers. However, the external and internal integration perform different functions in terms of supply chain integration context. As external integration observes the significance of developing interactive and close associations with the suppliers and customers, and internal integration observes that the departments under manufacturer must function like an integrated process. However, both integrations are essential to enable the members of supply chain to perform as a joint body for maximizing the supply chain's value (Tan and Sousa, 2015).

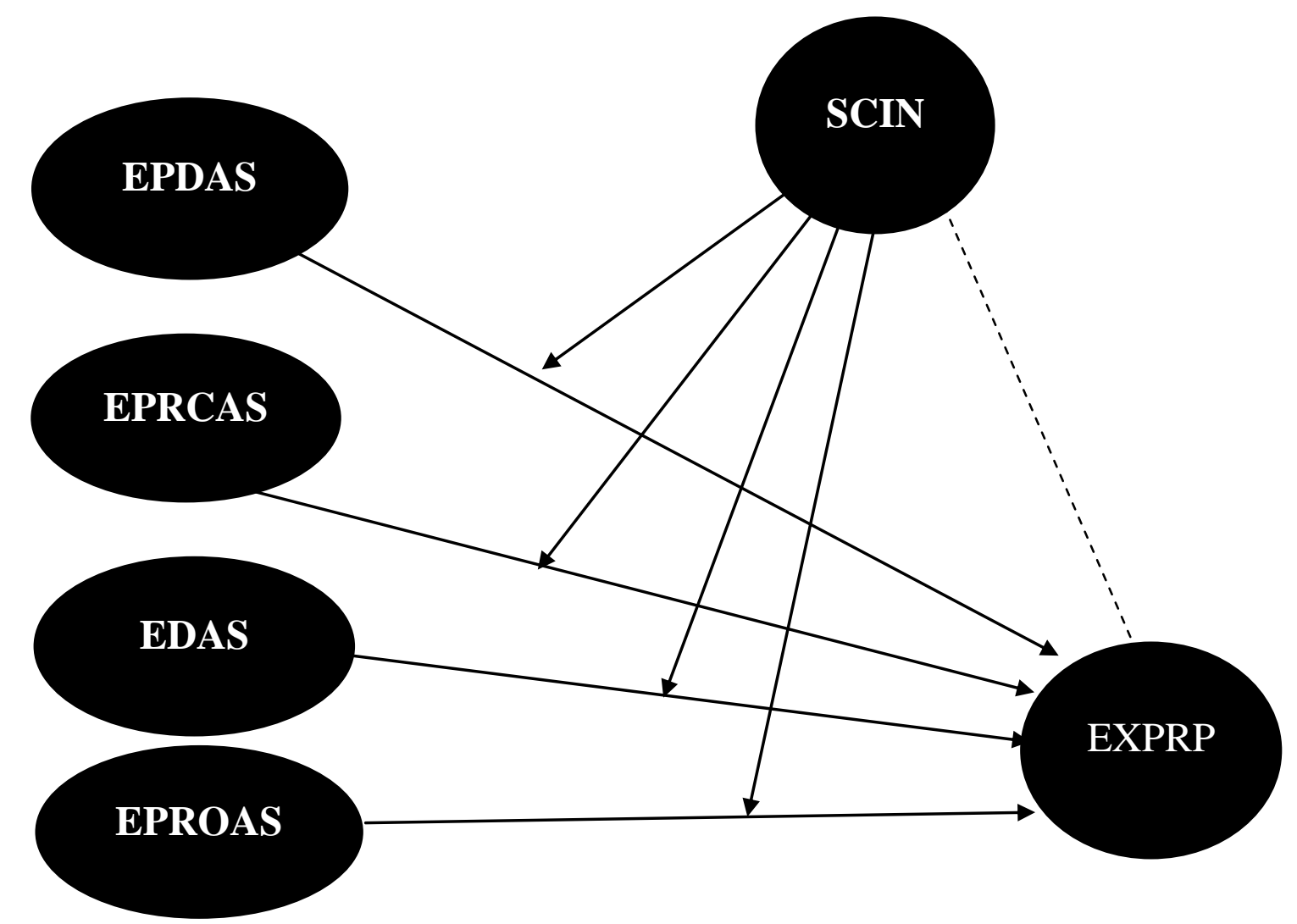

Figure 1: Conceptual Framework

On the basis of literature reviewed we have drawn the following hypothesis

H1: Export product adaption strategy (EPDAS) has significant impact on the export performance (EP).

H2: Export price adaption strategy (EPRCAS) has significant impact on the export performance (EP).

H3: Export distribution adaption strategy (EDAS) has significant impact on the export performance (EP).

H4: Export promotion adaption strategy (EPROAS) has significant impact on the export performance.

H5: Supply chain integration (SCI) has a significant impact on the export performance (EP).

H6: Supply chain integration (SCI) moderates the relationship between export product adaption strategy (EPDAS) and export performance (EP). 
H7: Supply chain integration (SCI) moderates the relationship between export price adaption strategy (EPRCAS) and export performance (EP)

H8: Supply chain integration (SCI) moderates the relationship between export distribution adaption strategy (EDAS) and export performance (EP).

H9: Supply chain integration (SCI) moderates the relationship between export promotion adaption strategy (EPROAS) and export performance (EP).

\section{METHODOLOGY}

The study was both descriptive and correlational in nature. The descriptive parts included profile of exporters and subject matter ratings while the correlational part established the association between international marketing programme and export performance. The research was designed based on the scientific method of hypothetico-deductive method. According to (Singh and Mahmood, 2014). The hypothetico-deductive method consists of seven steps that encompass a broad problem or issue identification, problem statement definition, hypotheses development, measures determination, data collection, analysis and interpretation of data. Deductive approach is a main aspect of this method where a general theoretical framework is adopted and applied to a certain practical case. The theoretical foundations were established through relevant past researches. For this study, a quantitative survey research approach was adopted. This survey research approach involved setting research objectives, designing the research, developing a reliable and valid research instrument, executing the survey, collecting and analyzing data and finally interpreting and reporting the findings. The study was a cross-sectional one where the research is conducted at a particular time as it is suitable for an academic research due to time constraint (Nazal, 2017; Nejad et al., 2017; Singh et al., 2017; Nazmi et al., 2018). This research employed an e-mail questionnaire survey to gather data for statistical testing of the formulated hypotheses. This survey method was selected due to the advantage of a wide geographical coverage in less time and with lower costs. This survey research method was chosen where it involved methods of gathering information from people in the natural setting. In other words, it was a field research that is conducted in its natural setting where a correlational study 58 was generally carried out in a non-contrived environment where events are left to happen in its normal setting without any researcher interference. The survey was carried out with a specific purpose of generalising the results to the population which also had a relatively high validity as the questions asked were directly addressing the underlying items of a dimension.

\section{RESULTS}

Regression explain how much of the variation in the dependent variable of export performance was caused by the independent variables of export marketing adaptation strategies. In other words, it established the predictive ability of different export marketing adaptation strategies as the set of independent variables, on export performance which is the dependent variable. This was performed by including all the independent variables into the analysis through a simultaneous or standard multiple regression. The analysis indicated the statistical significance of the individual independent variables as well as the overall model.

In performing multiple regressions, a correlation matrix was produced not only showing the relationship between the outcome variable and the predictor variables but also the relationship among the independent variables. High correlation among these independent variables would result in the problem of multicollinearity and thus adverse effect of the stability of the parameter estimates. To assess multicollinearity, the bivariate correlation between two independent variables indicated in the correlation matrix was checked. If among the independent variables correlation coefficient is 0.70 or more, omission of one variable would be considered to solve the problem of multicollinearity. As part of the multiple regression analysis in SPSS, collinearity statistics in the form of variance inflation factors (VIF) were computed to evaluate multicollinearity. The presence of multicollinearity would be indicated by a VIF score of above 10. In other words, if the VIF score was below 10, there would be no violation of the multicollinearity assumption.

Cronbach alpha values have been estimated for checking the reliability of variables. In order to validate that all the measured items have high factor loadings and reliability, validity test was performed. The ability of an item to estimate what it should estimate is referred as validity.

Table 1: Reliability

\begin{tabular}{c|c|c|c}
\hline & CR & AVE & Cronbach Alpha \\
\hline EPDAS & 0.925 & 0.872 & 0.985 \\
\hline IEPRCAS & 0.702 & 0.777 & 0.924 \\
\hline EDAS & 0.920 & 0.821 & 0.873 \\
\hline EPROAS & 0.812 & 0.832 & 0.926 \\
\hline SCI & 0.861 & 0.831 & 0.923 \\
\hline EP & 0.831 & 0.842 & 0.919 \\
\hline
\end{tabular}

Factor analysis involves the reduction of data for summarising the structure of variable. The other two categories of factor analysis are explanatory and confirmatory factor analysis. The correlation structure against the set structure is analyzed in 
the confirmatory factor analysis. It is estimated whether the criterion of goodness of fit is satisfied or not. The correlation structure of the data is assessed in exploratory factor analysis. It is also regarded as reduction process for the data. The variables supportive in the estimation of factors included in the model are also identified. It is observed in confirmatory factor analysis whether there exists any correlation among the observed variables and the factors are reliable. Moreover, the estimation of every factor is supported by the observed variables. For internal reliability and discovering the structuring factors, EFA can be used. However, the method is not good for theory testing. The association among the variables can be simplified and described through this analysis. For theory testing, CFA approach is considered effective.

When the p-value for Bartlett Sphericity is less than 0.05 , it reflects that the factor analysis is effective. The value needs to be above 0.6 for KaiserMeyer-Olkin case. When the value is above 0.6 , it reflects there is a need to add more variables in the model or collect more data. The sampling adequacy measure should be greater than 0.50 . It is suggested to eliminate the variables having item loadings lesser than 0.05 . In measuring the reliability of an item, it is estimated whether there is any error or bias. It is ensured through reliability test that the estimating items are stable at a given time. The value lies within 0-1. Higher internal consistency is indicated through the high value of Cronbach alpha. Therefore, the internal consistency among the variables is determined through Cronbach alpha. The low range value of reliability test came 0.717 and high range as 0.917. To observe the value of consistency, a rule of thumb is used. According to rule of thumb, the acceptable value is considered to be 0.50 or above. When the value is below 0.05 , it is not accepted. The desired range of value for reliability is $0.5-0.6$. The significance of the path coefficients was assessed using the standard bootstrapping procedure, which included 5000 bootstrap samples and 266 cases as recommended.

Table 2: Direct Effect

\begin{tabular}{l|l|l|l|l}
\hline & $(\boldsymbol{\beta})$ & SD & T-value & P-Values \\
\hline H1 & 0.211 & 0.135 & 3.211 & 0.000 \\
\hline H2 & 0.357 & 0.152 & 3.678 & 0.000 \\
\hline H3 & 0.321 & 0.178 & 3.321 & 0.000 \\
\hline H4 & 0.342 & 0.165 & 3.234 & 0.000 \\
\hline H5 & 0.451 & 0.221 & 3.345 & 0.000 \\
\hline
\end{tabular}

The moderation effect is shown in table 3

Table 4: Indirect Effect

\begin{tabular}{l|l|l|l|l}
\hline & $(\boldsymbol{\beta})$ & SD & T-value & P-Values \\
\hline H6 & 0.211 & 0.135 & 3.211 & 0.000 \\
\hline H7 & 0.357 & 0.152 & 3.678 & 0.000 \\
\hline H8 & 0.453 & 0.187 & 3.768 & 0.000 \\
\hline H9 & 0.408 & 0.132 & 3.968 & 0.000 \\
\hline
\end{tabular}

\section{CONCLUSION}

Export Marketing Strategy and Export Performance In a seminal work on export performance, investigate the relationship between marketing strategy and export performance. Information is gathered via personal interviews with management personnel involved in export marketing. A pilot study with export marketing managers is conducted to validate the content of the questionnaire, where variables and scales considered irrelevant are taken out in the final instrument. The sampling frame consisted of export companies compiled from both the government export development agencies and from various business associations related to trade given the internationalization of business today, it illustrates the importance of companies looking for overseas market opportunities for the capture of and sustainability of competitive advantage. Following the success of companies from newly developed nations such as the Far East Asian nations of the Republic of Korea and the Republic of China, Taiwan and South East Asian countries such as Singapore, emerging economies are shifting to external sector growth through export industries from the internal sector growth of import substitutes industries. Thus, the current study is interested in exploring the nexus between supply chain integration, export marketing strategies and export performance of Indonesian manufacturing firms. Employing the survey-based methodology, the SEM-PLS technique is used to test the hypothesized relationships. So, the current study has used SEM-PLS as a statistical tool to answer the research questions raised in this study and research objectives envisaged in the current study. The findings of the study have provided support to the theoretical foundation and proposed hypothesis of the current study. Current study will be helpful for policymakers and practitioners in understanding the issues related to supply chain risk, supply chain integration and supply chain agility. In the author's knowledge this is among very few pioneering studies on this issue.

\section{REFERENCES}

1. Aksoy, H., 2017. How do innovation culture, marketing innovation and product innovation affect the market performance of small and medium-sized enterprises (smes). Technology in Society, 51: 133-141. https://doi.org/10.1016/j.techsoc.2017.08.005 
2. Azar, G. and F. Ciabuschi, 2017. Organizational innovation, technological innovation, and export performance: The effects of innovation radicalness and extensiveness. International Business Review, 26(2): 324-336.

https://doi.org/10.1016/j.ibusrev.2016.09.002

3. Basheer, M., M. Siam, A. Awn and S. Hassan, 2019. Exploring the role of tqm and supply chain practices for firm supply performance in the presence of information technology capabilities and supply chain technology adoption: A case of textile firms in pakistan. Uncertain Supply Chain Management, 7(2): 275-

288.https://doi.org/10.5267/j.uscm.2018.9.001

4. Chen, J., C.M. Sousa and X. He, 2016. The determinants of export performance: A review of the literature 2006-2014. International Marketing Review, 33(5): 626-670.https://doi.org/10.1108/IMR-10-2015-0212

5. Cui, A.P., M.F. Walsh and S. Zou, 2014. The importance of strategic fit between host-home country similarity and exploration exploitation strategies on small and medium-sized enterprises' performance: A contingency perspective. Journal of International Marketing, 22(4): 67-85.https://doi.org/10.1509/jim.14.0045

6. Descotes, R.M. and B. Walliser, 2018. International marketing related competences and smes' export performance during the recession. Projects/Proyectica/Projectique(3): 61-82.https://doi.org/10.3917/proj.021.0061

7. Durmuşoğlu, S.S., G. Apfelthaler, D.Z. Nayir, R. Alvarez and T. Mughan, 2012. The effect of government-designed export promotion service use on small and medium-sized enterprise goal achievement: A multidimensional view of export performance. Industrial marketing management, 41(4): 680-

691.https://doi.org/10.1016/j.indmarman.2011.09.016

8. Fernández-Mesa, A. and J. Alegre, 2015. Entrepreneurial orientation and export intensity: Examining the interplay of organizational learning and innovation. International Business Review, 24(1): 148-156.

https://doi.org/10.1016/j.ibusrev.2014.07.004

9. Filipe Lages, L. and D.B. Montgomery, 2005. The relationship between export assistance and performance improvement in portuguese export ventures: An empirical test of the mediating role of pricing strategy adaptation. European Journal of Marketing, 39(7/8): 755-784.https://doi.org/10.1108/03090560510601752

10. Gkypali, A., A. Rafailidis and K. Tsekouras, 2015. Innovation and export performance: Do young and mature innovative firms differ? Eurasian Business Review, 5(2): 397-415.https://doi.org/10.1007/s40821-015-0030-4

11. Hafeez, M.H., M.F. Basheer, M. Rafique and S.H. Siddiqui, 2018. Exploring the links between tqm practices, business innovativeness and firm performance: An emerging market perspective. Pakistan Journal of Social Sciences (PJSS), 38(2): 485-500.

12. He, X., K.D. Brouthers and I. Filatotchev, 2013. Resource-based and institutional perspectives on export channel selection and export performance. Journal of Management, 39(1): 27-47.https://doi.org/10.1177/0149206312445926

13. Helleiner, E. and J. Kirshner, 2014. The great wall of money: Power and politics in China's international monetary relations. Cornell University Press.

14. Hiremath, G.S. and J. Kumari, 2014. Stock returns predictability and the adaptive market hypothesis in emerging markets: Evidence from india. SpringerPlus, 3(1): 428.https://doi.org/10.1186/2193-1801-3-428

15. Julian, C.C., 2018. The theoretical underpinnings of government policy, turbulence and performance in the service sector: A conceptual framework. Journal of Financial Services Marketing, 23(1): 1-11.

https://doi.org/10.1057/s41264-018-0041-1

16. Julian, C.C. and A. O'Cass, 2004. The antecedents of export marketing performance: An australian perspective. Journal of Asia Pacific Marketing, 3(2): 99.https://doi.org/10.1300/J098v05n01_02

17. Lee, C. and D.A. Griffith, 2004. The marketing strategy-performance relationship in an export-driven developing economy: A korean illustration. International Marketing Review, 21(3): 321-334. https://doi.org/10.1108/02651330410539648

18. Lengler, J.F., C.M. Sousa and C. Marques, 2013. Exploring the linear and quadratic effects of customer and competitor orientation on export performance. International Marketing Review, 30(5): 440-468. https://doi.org/10.1108/IMR-03-2011-0087

19. Magnusson, P., S.A. Westjohn, A.V. Semenov, A.A. Randrianasolo and S. Zdravkovic, 2013. The role of cultural intelligence in marketing adaptation and export performance. Journal of International Marketing, 21(4): 44-61. https://doi.org/10.1509/jim.13.0055

20. Martin, S.L., R.G. Javalgi and E. Cavusgil, 2017. Marketing capabilities, positional advantage, and performance of born global firms: Contingent effect of ambidextrous innovation. International business review, 26(3): 527-543. https://doi.org/10.1016/j.ibusrev.2016.11.006

21. Morgan, N.A., C.S. Katsikeas and D.W. Vorhies, 2012. Export marketing strategy implementation, export marketing 
capabilities, and export venture performance. Journal of the Academy of Marketing Science, 40(2): 271-289. https://doi.org/10.1007/s11747-011-0275-0

22. Moussa, A., 2018. Does the agricultural sector contribute to the economic growth in case of the republic of benin? Journal of Social Economics Research, 5(2): 85-93.https://doi.org/10.18488/journal.35.2018.52.85.93

23. Mungwari, T., 2018. Media framing of zanu pf internal succession struggles: Mnangagwa and the military factor. American Journal of Social Sciences and Humanities, 3(1): 1-21.https://doi.org/10.20448/801.31.1.21

24. Myeni, S.L. and B.Y. Mvuyana, 2018. Participatory processes in planning for self-help housing provision in south africa: Policies and challenges. International Journal of Public Policy and Administration Research, 5(1): 24-36.

25. Navarro, A. and A. Boveris, 2009. Brain mitochondrial dysfunction and oxidative damage in parkinson's disease. Journal of Bioenergetics and Biomembranes, 41(6): 517-521.https://doi.org/10.1007/s10863-009-9250-6

26. Navarro, A., F. Losada, E. Ruzo and J.A. Diez, 2010. Implications of perceived competitive advantages, adaptation of marketing tactics and export commitment on export performance. Journal of world business, 45(1): 49-58. https://doi.org/10.1016/j.jwb.2009.04.004

27. Nazal, A.I., 2017. Financial tables reports gaps in jordanian islamic banks. The Economics and Finance Letters, 4(2): 915.https://doi.org/10.18488/journal.29.2017.42.9.15

28. Nazmi, N.F.M., R. Ab Rashid, N.A.M. Zani, N.F.A. Jabar and M.F. Aziz, 2018. Discourse analysis on international online news reports of Manchester bombing. International Journal of Asian Social Science, 8(9): 660-668. https://doi.org/10.18488/journal.1.2018.89.660.668

29. Nejad, M.A.R.S., F.N.J. Agha and Y.F. Zadeh, 2017. Qspm usage in swot analysis as a tool for strategic management of caspian sea coasts (case study: Tourism development in caspian eastern coast at gilan province). Journal of Tourism Management Research, 4(1): 1-11.https://doi.org/10.18488/journal.31.2017.41.1.11

30. Ruskowski, I. and P. Pauwels, 2016. A dynamic perspective on internet capabilities and export marketing performance. In: 42nd Annual Conference of the European International Business Academy (EIBA) Vienna, Austria.

31. Ruzo, E., F. Losada, A. Navarro and J.A. Díez, 2011. Resources and international marketing strategy in export firms: Implications for export performance. Management Research Review, 34(5): 496-518. https://doi.org/10.1108/01409171111128698

32. Singh, H., R. Jamil, M.B. Baroto, M. Hussin, Y. Boyi and S. Singh, 2017. Impact of financial and non-financial incentives on employee performance. Advanced Science Letters, 23(1): 146-150.https://doi.org/10.1166/asl.2017.7181

33. Singh, H. and R. Mahmood, 2014. Aligning manufacturing strategy to export performance of manufacturing small and medium enterprises in malaysia. Procedia-Social and Behavioral Sciences, 130: 85-95.

https://doi.org/10.1016/j.sbspro.2014.04.011

34. Sousa, C.M. and J. Lengler, 2009. Psychic distance, marketing strategy and performance in export ventures of brazilian firms. Journal of Marketing Management, 25(5-6): 591-610.https://doi.org/10.1362/026725709X461876

35. Sousa, C.M., F.J. Martínez-López and F. Coelho, 2008. The determinants of export performance: A review of the research in the literature between 1998 and 2005. International Journal of Management Reviews, 10(4): 343-374. https://doi.org/10.1111/j.1468-2370.2008.00232.x

36. Stoian, M.-C., A. Rialp and J. Rialp, 2011. Export performance under the microscope: A glance through spanish lenses. International Business Review, 20(2): 117-135.https://doi.org/10.1016/j.ibusrev.2010.07.002

37. Tan, Q. and C.M. Sousa, 2015. Leveraging marketing capabilities into competitive advantage and export performance. International Marketing Review, 32(1): 78-102.https://doi.org/10.1108/IMR-12-2013-0279 